11 Scottish Health Action on Alcohol Problems. Alcohol: Price, Policy and Public Health: Report on the Findings of the Expert Workshop on Price Convened by SHAAP. Scottish Health Action on Alcohol Problems, 2007.

12 Gruenewald $\mathrm{P}$, Ponicki W, Holder $\mathrm{H}$, Romelsjö A. Alcohol prices, beverages quality, and the demand for alcohol: quality substitution and price elasticies. Alcohol Clin Exp Res 2006; 30: 96-105.

13 Brennan A, Purshouse R, Taylor K, Rafia R, Meier P, Booth A, et al. Independent Review of the Effects of Alcohol Pricing and Promotion: Part $B$. Modelling the Potential Impact of Pricing and Promotion Policies for Alcohol in England: Results from the Sheffield Alcohol Policy Model. Version 2008 (1-1). University of Sheffield, 2008.

14 Gray D, Saggers S, Atkinson D, Sputore B, Bourbon, D. Beating the grog: an evaluation of the Tennant Creek liquor licensing restrictions. In Indigenous
Australian Alcohol and Other Drug Issues: Research from the National Drug Research Institute (eds D Gray, S Saggers): 17-28. National Drug Research Institute, 2002.

15 Stockwell, T, Auld CM, Zhao J, Martin G. Does minimum pricing reduce alcohol consumption? The experience of a Canadian province. Addiction 2012; 107: 912-20.

16 Drummond, DC. An alcohol strategy for England: the good, the bad and the ugly. Alcohol Alcohol 2004; 39: 377-9.

17 Anderson P, Baumberg B. Alcohol in Europe. Institute of Alcohol Studies, 2006.

18 Arnot R. Alcohol pricing: will health lobby hold sway? The Grocer, 18 February 2012. poems
by
doctors

\section{Care in the Community}

\section{Raymond Miller}

Most often I spot them way off in the distance:

something in the gait and the weight of their symptoms

bears the stamp of repeat prescriptions.

Sets alarm bells screeching and I turn on a sixpence

To cross roads inventing a previous engagement,

catch a flower arrangement, bend to tie laces,

bury my head in shop windows replete

with cheap trinkets. I treat light on my feet

but dejected spirits make cock-crow visits,

patches of ice combine with the rain

to throw me off-balance; I clutch at displacement

when meeting ex-patients again.

Or else my elbow shudders at the finger

As "Hello stranger!" wraps round my shoulder.

I spin to a name that I can't remember;

a drug, a diagnosis or simply disorder.

The furrowed flesh of distress and despond;

failure to bond and exasperation;

the trial separation from errant husbands;

scars and bruises borne by the infant;

the rooted abhorrence roared at the parents

have eroded my epithets of empathy,

I've shovelled that dirty laundry

into yellow plastic bags for waste disposal

I no longer dance to the non-judgemental.

What's once contemplated can't be unthought:

they take me at face value; I sell them short.

This poem is from The Hippocrates Prize 2011, published by The Hippocrates Prize in association with Top Edge Press (c) Raymond Miller.

Chosen by Femi Oyebode.
The British Journal of Psychiatry (2012)

201, 171. doi: 10.1192/bjp.bp.111.10310 